\section{Avaliação da PCR e hibridização com sondas moleculares como ferramentas para o diagnóstico e caracterização de Yersinia pestis}

As técnicas habitualmente empregadas no diagnóstico da peste são demoradas, dispendiosas e nem sempre os resultados são satisfatórios. A identificação da Yersinia pestis, agente causador da peste, é muitas vezes prejudicada nos processos de conservação das amostras e seu transporte dos locais da coleta aos centros de diagnóstico. Nova metodologia se faz necessária para aplicação nas atividades de diagnóstico e controle da peste. Com este objetivo foram realizados ensaios baseados na técnica de PCR e hibridização com sondas moleculares não radioativas. Foi desenvolvido um teste simples e rápido para amplificação do gene caf1 da Y. pestis diretamente nos baços dos roedores através da PCR, seguido de Nested-PCR. A técnica Nested-PCR foi também usada no exame de amostras após conservação no meio de Cary \& Blair, simulando condições de campo. Tanto no exame direto quanto em amostras conservadas no meio de transporte, a Nested-PCR revelouse mais eficaz do que a cultura. Outra variação da PCR, a técnica Multiplex-PCR, que usa múltiplos pares de iniciadores dirigidos a vários genes e que amplificam fragmentos de tamanhos diferentes mostrou-se promissora para o diagnóstico da peste diretamente no sangue dos pacientes. O emprego da Multiplex-PCR com iniciadores direcionados a três genes de virulência plasmidiais (caf1, IcrV pla) e um gene cromossômico (irp2) da Y. pestis, permite um diagnóstico mais rápido que o tradicional, ao mesmo tempo que caracteriza as propriedades de virulência da cepa infectante. A técnica RAPD, outra variação da PCR, que usa apenas um iniciador aleatório, em condições de baixa estringência, foi usada para analisar uma amostragem de 29 cepas de Y. pestis originadas do Foco Pestoso da Chapada do Araripe, revelando que as cepas isoladas de diferentes hospedeiros, durante um período de 10 anos são genotipicamente homogêneas. Foram construídas

\section{Evaluation of the PCR and hibridization with molecular probes as tool for the diagnosis and characterization of Yersinia pestis}

The techniques usually employed for the diagnosis of plague are laborious, time-consuming and often give poor results. Furthermore, the identification of Yersinia pestis, the causative agent of plague, can be hampered by inadequate shipment of the samples from their collection to the examination on the diagnostic centers. Hence, the development of new methods for plague diagnosis is sought after and would be useful for the plague control program. With this purpose we carried out PCR-based assays and DNA hybridization procedures with non-radioactive probes. We developed a quick and simple Nested-PCR-based procedure for amplification of $Y$. pestis caf1 gene directly from rodents' spleens. Nested-PCR technique was also employed with success for examination of samples preserved into Cary \& Blair medium, mimicking field procedures, and proved to be more effective than the culture, both for direct examination of samples or on Cary \& Blair preserved samples. Other PCR-based procedure that uses multiple primers directed to different targets, proved to be promising for the identification of $Y$. pestis directly on the blood of the plague patients. The Multiplex-PCR technique directed to three plasmidial genes (caf1, lcrV, pla) and to a chromosomal gene (irp2), allows the rapid detection of $Y$. pestis and the identification of four virulence markers on the strains. RAPD, other PCR-based procedure which uses only one primer on low-stringency conditions, was employed on the study of $29 \mathrm{Y}$. pestis strains originated from different hosts, during a period of 10 years, from the Chapada do Araripe plague focus, showing that the genome of all the strains analyzed are homogeneous, regardless their origin (host and year of isolation). We constructed four digoxigenin-labeled DNA probes, by PCR amplification, with primers directed to the genes caf1, IcrV, pla and irp2. The Caf1 probe was used for $Y$. pestis detection by dot-blot. However, it

Recebido para publicação em 19/2/99. 
sondas moleculares, marcadas com digoxigenina, por meio de PCR com iniciadores dirigidos aos genes caf1, IcrV pla e irp2. A sonda Caf1 foi usada em ensaios de hibridização através de dot blot, revelando-se pouco sensível e pouco específica, não sendo por isto recomendável para o diagnóstico da peste. Em contrapartida, através da hibridização com as sondas, foi demonstrada uma homologia entre bandas extras, crípticas de DNA encontradas em algumas cepas de $Y$. pestis brasileiras e os plasmídeos típicos. does not show sensibility or specificity enough to be recommended for plague diagnosis. Nevertheless, the probes were useful to show a relationship among additional cryptic DNA bands and the typical plasmids on Y. pestis Brazilian strains.

\section{Nilma Cintra Leal}

Tese apresentada ao Centro de Ciências Biológicas da

Universidade Federal de Pernambuco

para obtenção do Título de Doutor.

Recife, PE, Brasil, 1998 